\title{
A Comparison of Institutional Approaches to CEAB Graduate Attribute Requirements
}

\author{
James Kaupp ${ }^{1}$, Brian Frank ${ }^{1}$, Robert Brennan ${ }^{2}$, Susan McCahan ${ }^{3}$, Lata Narayanan ${ }^{4}$, Peter Ostafichuck, \\ Nariman Sepehri ${ }^{6}$, and K. Christopher Watts $^{7}$ \\ ${ }^{1}$ Queen's University, ${ }^{2}$ University of Calgary, ${ }^{3}$ University of Toronto, ${ }^{4}$ Concordia University, ${ }^{5}$ University of British \\ Columbia, ${ }^{6}$ University of Manitoba, ${ }^{7}$ Dalhousie University \\ brian.frank@queensu.ca
}

\begin{abstract}
This paper describes and compares the different approaches of seven Canadian institutions to the Canadian Engineering Accreditation Board (CEAB) requirements for continuous quality improvement using graduate attributes. Program approaches are compared by: program objectives \& management, indicators, curriculum mapping, assessment \& data collection and curriculum improvement. The significant differences include approaches to curriculum mapping, data collection and curriculum improvement.
\end{abstract}

Keywords: CEAB, Graduate Attributes, Curriculum Improvement, Assessment, Curriculum Mapping, Data Collection

\section{INTRODUCTION}

In 2008 the Canadian Engineering Accreditation Board (CEAB) added supplemented its policy by requiring programs to implement a continuous quality improvement process that demonstrated graduating students possess twelve key attributes. The CEAB requires programs to have a system for the assessment of, and curriculum improvement using, graduate attributes by June 2015 (CEAB Accreditation Section 3.1 and 3.2). Instead of dictating terms and methods by which institutions should follow, CEAB left the development of the assessment and continuous improvement process up to the individual institutions. This allows for a large measure of freedom and variety for institutions to adapt to the outcomes based accreditation and select methods and instruments contextually suited for fulfillment of CEAB Accreditation Sections 3.1 and 3.2.

The accreditation regulations required that programs demonstrate that processes are in place or are planned to be used to demonstrate that students possess the twelve graduate attributes, and that the results are being applied to the further development of the program. The specific requirements include [1]: a) A set of indicators that describe specific abilities expected of students to demonstrate each attribute

b) A curriculum map describing where attributes are developed and assessed within the program

c) A description of how the indicators were or will be assessed (e.g. reports, oral presentations, exams, etc.)

d) An evaluation of the data collected including analysis of student performance relative to program expectations

Each of these must specifically address each graduate attribute.

There are many possible approaches to satisfying these key requirements. The Engineering Graduate Attribute Development (EGAD) Project, a collaborative effort to assist colleagues and institutions transition to $\mathrm{CEAB}$ requirements, has developed a 5-step data informed approach to curriculum or program evaluation [2]. Other frameworks include curriculum planning processes [3], ABET assessment planning [4], and CDIO [5-7]. The purpose of this paper is to present and compare the different approaches of seven institutions to provide a resource and greater understanding to colleagues and institutions developing their processes to comply CEAB accreditation sections 3.1 and 3.2.

\section{APPROACH SUMMARIES AND STATUS}

The institutions sharing their approach to $\mathrm{CEAB}$ accreditation are: 
- Concordia University

- Dalhousie University

- Queen's University

- University of British Columbia

- University of Calgary

- University of Manitoba

- University of Toronto

The sections below describe the process followed by each institution.

\subsection{Concordia University}

Concordia started their graduate attribute process in 2009, following the EGAD 5-step guidelines. A committee comprised of departmental representatives was formed and program objectives were developed, but without clear connection to GA. Faculty-wide indicators have been developed for 9 attributes, and curriculum mapping has been completed, linking all programs to GA. Course coordinators and instructors create assessment tools with rubric evaluation on a 4-tiered scale becoming more common. Indirect assessment of all 12 attributes is done through survey of recent program graduates, alumni and employers. Data and assessment tool collection is centralized by a Concordia developed a custom software tool, Attribute Assessment System (AAS). Concordia follows a three-year assessment cycle, staggering assessment of 4 attributes in 3 groups resulting in two cycles of GA assessment and improvement over an accreditation cycle. Currently, Concordia is in the preliminary data analysis stage using data collected from 2010/2011 and 2011/2012.

\subsection{Dalhousie University}

Dalhousie started their graduate attribute process in 2009, and have developed an independent approach. A Graduate Attribute Committee (GAC) was established and developed faculty-wide indicators, focusing on course based outcomes rather than program-wide objectives. Curriculum mapping was completed for some programs and includes options for co-op, student portfolio and student self-assessment. Assessment is the instructor's responsibility with the GAC preforming a guiding role. 4-tiered indicator-linked example rubrics were created by the GAC for demonstration purposes and a minimal standard for future direct assessments. Plans are in place for indirect assessment of graduate attributes using the Co-op program. A commercial software package, eLumen, is used for data collection as well as endpoint and on-demand analysis of GA. Currently, Dalhousie is in the process of entering pilot data into eLumen[8], testing their course assessment and data collection process using data from 2010/2011 and 2011/2012.

\subsection{Queen's University}

Queen's started the graduate attribute assessment process in 2009, following the principles in the EGAD 5step guide. Faculty-wide indicators were developed by seven committees comprised of undergraduate chairs and experts in specific areas. The curriculum was mapped via CurricKit, a customized software package being developed by the University of Guelph. Common assessment tools are instructor developed leveled rubrics with four tiers (Below, Marginal, Meets and Exceeds Expectations). Data collection is done through a learning management system (Moodle) with quantitative evaluation using leveled performance assessment longitudinally within academic year. Queen's has piloted GA assessment faculty-wide in first, second and program specific final year courses using faculty-wide indicators (10 of 12 for first year and 8 out of 12 for fourth year). Currently Queen's is implementing program improvement processes and developing design skill assessment tools as well as conducting indirect assessment using student survey and focus groups to gauge student comprehension and perception of graduate attributes. More detail about the process at Queen's is described in past CEEA proceedings [9-11].

\subsection{University of British Columbia}

UBC started their graduate attribute process in 2010, following a process flow similar to the EGAD 5-step guidelines. A Graduate Attributes Committee (GAC) consisting of representatives from the ten UBC engineering programs was formed, and outcomes and indicators from other institutions and jurisdictions were reviewed. Faculty-wide indicators were selected and developed for all 12 attributes. A GA curriculum mapping survey was created and distributed to all teaching faculty. Survey results were used to determine courses for GA assessment in each program. GAC members approached course coordinators and instructors in their respective programs to identify and/or create assessment tools for the courses selected for GA assessment. Progress beyond this stage has varied by program: in some programs data collection has not yet begun, while in others a majority of indicators have been assessed (the leading program has completed a preliminary analysis of 43 of 60 indicators). In some programs, multiple indirect assessment of all 12 attributes has also been done through various surveys of current students. Currently, programs at UBC are working independently on preliminary data analysis, refining indicators, and developing and extending assessment tools. 


\subsection{University of Calgary}

The University of Calgary started the graduate attribute assessment process in 2008. The CDIO Syllabus was used as a starting point for developing faculty-wide indicators and curriculum mapping, as several studies have investigated the alignment between CDIO and CEAB GA[5], [7], [12]. Direct in-class summative assessments are used with targeted performance levels establish per indicator. Indirect assessment of final year capstone courses, along with alumni and industry perspectives, were collected via surveys. Continuous Improvement is currently being prepared, with data collected since 2010 being analyzed. Calgary follows a multi-year flexible data collection plan, with direct assessment of 4 attributes per year with indirect assessments of all $12 \mathrm{GA}$ are conducted yearly. This results in 2-to-3 sets of direct assessments every accreditation cycle, with the option to refine the collection plan to address potential underdeveloped GA.

\subsection{University of Manitoba}

The University of Manitoba started their graduate attribute process in 2010, following the EGAD 5-step guidelines. A faculty led committee was formed and program objectives were developed. Faculty-wide indicators were developed for all attributes, and coursebased curriculum mapping was completed connecting each course learning objective to graduate attributes and expected competency levels. Course instructors recommend assessment tools to assess learning outcomes and indicators, with tiered rubrics being developed for each set of indicators. Indirect assessment of attributes is conducted by a survey of industry contacts, graduates, alumni and co-op students. Additional indirect data is gathered through Industry \& Alumni and student forums. A Curriculum Management Committee (CMC) conducts data analysis and curriculum improvement as required. Currently, the University of Manitoba has piloted direct assessment of 4 attributes and the CMC is currently analyzing the results of both direct and indirect evaluations and curriculum improvement is ongoing, with refinement of indicators, rubrics and assessment tools resulting from the pilot.

\subsection{University of Toronto}

The University of Toronto started the graduate attribute process in 2009, following the EGAD 5-step guidelines. Created a Graduate Attributes Committee (GAC) to develop the process at the faculty and departmental level. Global faculty outcomes and indicators were developed, with the intent for departments to modify indicators to suit their needs. Curriculum mapping was of departmental domain, with clear indication of where global outcomes were assessed. The GAC developed 4-tiered analytic rubrics for each GA to be used as a starting point and set a performance standard across the Faculty. Currently, UofT is reviewing pilot data from 2011 and developing course assessment and data collection processes. More details about the process at UofT is described in past CEEA proceedings [13-16].

\section{COMPARISON OF APPROACHES}

In order to determine common themes of the different approaches a categorical comparison is presented. The categories are: Program Objectives \& Management, Indicators, Curriculum Mapping, Assessment \& Data Collection, and Curriculum Improvement.

\subsection{Program Objectives and Management}

Table 1: Summary of Program Objectives and Management

\begin{tabular}{|c|c|c|}
\hline Institution & Management Structure & $\begin{array}{c}\text { Program } \\
\text { Objectives } \\
\end{array}$ \\
\hline $\begin{array}{l}\text { Concordia } \\
\text { University }\end{array}$ & $\begin{array}{l}\text { Collaborative management } \\
\text { between faculty and } \\
\text { departments }\end{array}$ & $\begin{array}{l}\text { Established, } \\
\text { no linked with } \\
\text { GA }\end{array}$ \\
\hline $\begin{array}{l}\text { Dalhousie } \\
\text { University }\end{array}$ & $\begin{array}{l}\text { Graduate Attribute } \\
\text { Committee (Faculty led) } \\
\text { with departmental } \\
\text { collaboration }\end{array}$ & $\begin{array}{l}\text { Not } \\
\text { Established }\end{array}$ \\
\hline $\begin{array}{l}\text { Queen's } \\
\text { University }\end{array}$ & $\begin{array}{l}\text { Guiding Committee } \\
\text { (Faculty led) with } \\
\text { departmental collaboration }\end{array}$ & $\begin{array}{l}\text { Not } \\
\text { Established } \\
\text { Program wide }\end{array}$ \\
\hline $\begin{array}{l}\text { University } \\
\text { of British } \\
\text { Columbia }\end{array}$ & $\begin{array}{l}\text { Graduate Attribute } \\
\text { Committee (Faculty led) } \\
\text { with departmental } \\
\text { collaboration }\end{array}$ & $\begin{array}{l}\text { Discussed, } \\
\text { Not } \\
\text { Established }\end{array}$ \\
\hline $\begin{array}{l}\text { University } \\
\text { of Calgary }\end{array}$ & $\begin{array}{l}\text { Guiding Committee } \\
\text { (Faculty led) with } \\
\text { departmental collaboration }\end{array}$ & $\begin{array}{l}\text { Not } \\
\text { Established }\end{array}$ \\
\hline $\begin{array}{l}\text { University } \\
\text { of } \\
\text { Manitoba }\end{array}$ & $\begin{array}{l}\text { Guiding Committee } \\
\text { (Faculty led) with } \\
\text { departmental collaboration }\end{array}$ & Established \\
\hline $\begin{array}{l}\text { University } \\
\text { of Toronto }\end{array}$ & $\begin{array}{l}\text { Graduate Attribute } \\
\text { Committee (Faculty led) } \\
\text { with departmental } \\
\text { collaboration }\end{array}$ & $\begin{array}{l}\text { Established } \\
\text { Global } \\
\text { Outcomes } \\
\text { (3 Per GA) }\end{array}$ \\
\hline
\end{tabular}

The common theme in the approach towards management of the process seems to gravitate towards a collaborative process, as shown in Table 1. A central faculty led governing body with departmental involvement appears to be the norm. Less common is the establishment of specific program objectives. Concordia and UofT have developed program objectives and global 
outcomes per attribute, respectively, with slight variations quantity and alignment with graduate attributes. The schools that did not establish program objectives either adopted the graduate attributes as the outcomes of their program (Queen's, Dalhousie and UBC) or have had other outcomes in place (Calgary using CDIO).

\subsection{Indicators}

Table 2: Summary of Indicators

\begin{tabular}{|c|c|c|c|}
\hline Institution & $\begin{array}{c}\text { Indicator } \\
\text { Development }\end{array}$ & Source & Application \\
\hline $\begin{array}{l}\text { Concordia } \\
\text { University }\end{array}$ & Faculty-wide & GA & $\begin{array}{l}\text { Selection } \\
\text { with } \\
\text { malleable } \\
\text { indicators }\end{array}$ \\
\hline $\begin{array}{l}\text { Dalhousie } \\
\text { University }\end{array}$ & Faculty-wide & GA & $\begin{array}{l}\text { Selection } \\
\text { only }\end{array}$ \\
\hline $\begin{array}{l}\text { Queen's } \\
\text { University }\end{array}$ & Faculty-wide & $\begin{array}{l}\text { CDIO } \\
\text { Syllabus, } \\
\text { EC 2000, } \\
\text { Washington } \\
\text { Accord } \\
\text { signatories }\end{array}$ & $\begin{array}{l}\text { Selection } \\
\text { only, with } \\
\text { additional } \\
\text { program- } \\
\text { specific } \\
\text { indicators }\end{array}$ \\
\hline $\begin{array}{l}\text { University } \\
\text { of British } \\
\text { Columbia }\end{array}$ & Faculty-wide & GA & $\begin{array}{l}\text { Selection } \\
\text { only }\end{array}$ \\
\hline $\begin{array}{l}\text { University } \\
\text { of Calgary }\end{array}$ & Faculty-wide & $\begin{array}{l}\text { CDIO } \\
\text { Syllabus }\end{array}$ & $\begin{array}{l}\text { Selection } \\
\text { only }\end{array}$ \\
\hline $\begin{array}{l}\text { University } \\
\text { of } \\
\text { Manitoba }\end{array}$ & Faculty-wide & GA & $\begin{array}{l}\text { Selection } \\
\text { only }\end{array}$ \\
\hline $\begin{array}{l}\text { University } \\
\text { of Toronto }\end{array}$ & Faculty-wide & $\begin{array}{l}\text { Global } \\
\text { Outcomes }\end{array}$ & $\begin{array}{l}\text { Selection } \\
\text { with } \\
\text { malleable } \\
\text { indicators }\end{array}$ \\
\hline
\end{tabular}

The development of faculty level indicators is common amongst all institutions as shown in Table 2. The main difference pertains to the source, or development material, of the indicators. The majority approach is to develop indicators directly from graduate attributes. The University of Calgary, having already implemented CDIO utilized the many outcomes from that program as a resource and selected 4-8 key indicators that were well aligned with graduate attributes. The application, or dictated use, of the indicators also shared a common element with the majority of the institutions dictating that instructors select the indicators to assess the attribute and not develop their own. Only two institutions developed malleable indicators, allowing instructors to tailor the indicators for their own use.

\subsection{Curriculum Mapping}

Table 3: Summary of Curriculum Mapping

\begin{tabular}{|c|c|c|c|}
\hline Institution & $\begin{array}{c}\text { Mapping } \\
\text { Method }\end{array}$ & $\begin{array}{c}\text { Mapping } \\
\text { Tool(s) }\end{array}$ & $\begin{array}{c}\text { Specialized } \\
\text { Options }\end{array}$ \\
\hline $\begin{array}{l}\text { Concordia } \\
\text { University }\end{array}$ & $\begin{array}{l}\text { Mapped } \\
\text { attributes } \\
\text { to } \\
\text { curriculum }\end{array}$ & $\begin{array}{l}\text { Graduate } \\
\text { Attributes \& } \\
\text { curriculum } \\
\text { information }\end{array}$ & N/A \\
\hline $\begin{array}{l}\text { Dalhousie } \\
\text { University }\end{array}$ & $\begin{array}{l}\text { Mapped } \\
\text { indicators } \\
\text { to } \\
\text { curriculum }\end{array}$ & $\begin{array}{l}\text { Faculty } \\
\text { indicators \& } \\
\text { curriculum } \\
\text { information }\end{array}$ & $\begin{array}{l}\text { Co-op } \\
\text { Program } \\
\text { Student } \\
\text { Portfolio \& } \\
\text { Student } \\
\text { Self- } \\
\text { assessment }\end{array}$ \\
\hline $\begin{array}{l}\text { Queen's } \\
\text { University }\end{array}$ & $\begin{array}{l}\text { Alignment } \\
\text { Mapping }\end{array}$ & CurriKit & N/A \\
\hline $\begin{array}{l}\text { University } \\
\text { of British } \\
\text { Columbia }\end{array}$ & $\begin{array}{l}\text { Mapped } \\
\text { attributes } \\
\text { to } \\
\text { curriculum }\end{array}$ & $\begin{array}{l}\text { Custom- } \\
\text { developed } \\
\text { survey }\end{array}$ & N/A \\
\hline $\begin{array}{l}\text { University } \\
\text { of Calgary }\end{array}$ & $\begin{array}{l}\text { Activities } \\
\& \\
\text { Outcomes } \\
\text { Mapping }\end{array}$ & $\begin{array}{l}\text { CDIO } \\
\text { Syllabus \& } \\
\text { ITU } \\
\text { Analysis }\end{array}$ & N/A \\
\hline $\begin{array}{l}\text { University } \\
\text { of Manitoba }\end{array}$ & $\begin{array}{l}\text { Mapped } \\
\text { indicators } \\
\text { to } \\
\text { curriculum }\end{array}$ & $\begin{array}{l}\text { Graduate } \\
\text { Attributes, } \\
\text { curriculum } \\
\text { information }\end{array}$ & N/A \\
\hline $\begin{array}{l}\text { University } \\
\text { of Toronto }\end{array}$ & $\begin{array}{l}\text { Mapped } \\
\text { objectives } \\
\text { to } \\
\text { curriculum }\end{array}$ & $\begin{array}{l}\text { Department } \\
\text { preference }\end{array}$ & N/A \\
\hline
\end{tabular}

There was a fair amount of institutional variation in curriculum mapping as shown in Table 3. The common approach was mapping indicators, attributes or program objectives to the curriculum embodying a bottom-up approach. These processes utilized curriculum maps and graduate attributes along with input from the management structure to complete the map. The University of Manitoba conducted mapping via many faculty and departmental workshops, producing course maps describing departmental graduate attribute content as a function of each course and Bloom's Taxonomy competency level. The University of Calgary utilized the activities and outcomes mapping in CDIO syllabus and alignment to CEAB GA along with an ITU analysis to map their curriculum. Queen's University utilized alignment mapping via the CurriKit tool, alongside 
faculty and departmental surveys to complete their curriculum map. Dalhousie also mapped attributes to specialized options (Co-op programs, Student Portfolio and Self-assessment) offered, giving them additional options to directly and indirectly assess GA. At the University of British Columbia, a custom online survey based on a modified ITU Analysis was developed and used to map attributes in the curriculum and to collect information on how attributes were assessed.

\subsection{Assessment \& Data Collection}

Table 4: Summary of Assessment \& Data Collection

\begin{tabular}{|c|c|c|c|}
\hline Institution & $\begin{array}{c}\text { Assessment } \\
\text { Type } \\
\end{array}$ & $\begin{array}{c}\text { Assessment } \\
\text { Tool(s) }\end{array}$ & $\begin{array}{c}\text { LMS \& Data } \\
\text { Collection }\end{array}$ \\
\hline $\begin{array}{l}\text { Concordia } \\
\text { University }\end{array}$ & $\begin{array}{l}\text { Direct \& } \\
\text { Indirect } \\
\text { (Graduates, } \\
\text { Alumni, } \\
\text { Employers) }\end{array}$ & $\begin{array}{l}\text { Instructor- } \\
\text { developed 4- } \\
\text { tiered rubrics } \\
\text { Surveys }\end{array}$ & AAS \\
\hline $\begin{array}{l}\text { Dalhousie } \\
\text { University }\end{array}$ & $\begin{array}{l}\text { Direct \& } \\
\text { Indirect (Co- } \\
\text { op Students) }\end{array}$ & $\begin{array}{l}\text { Customizable, } \\
\text { faculty-wide 4- } \\
\text { tiered rubrics } \\
\text { Surveys }\end{array}$ & eLumen \\
\hline $\begin{array}{l}\text { Queen's } \\
\text { University }\end{array}$ & $\begin{array}{l}\text { Direct } \\
\text { (embedded) } \\
\text { \& Indirect } \\
\text { (Graduates) }\end{array}$ & $\begin{array}{l}\text { Instructor- } \\
\text { developed 4- } \\
\text { tiered rubrics } \\
\text { Surveys } \\
\text { Focus Groups } \\
\text { Design } \\
\text { assessment tool }\end{array}$ & Moodle \\
\hline $\begin{array}{l}\text { University } \\
\text { of British } \\
\text { Columbia }\end{array}$ & $\begin{array}{l}\text { Direct } \\
\text { (embedded) } \\
\text { and Indirect } \\
\text { (Students \& } \\
\text { Co-op) }\end{array}$ & $\begin{array}{l}\text { Instructor- } \\
\text { developed 4- } \\
\text { tiered rubrics } \\
\text { Surveys } \\
\text { Some course } \\
\text { grades }\end{array}$ & N/A \\
\hline $\begin{array}{l}\text { University } \\
\text { of Calgary }\end{array}$ & $\begin{array}{l}\text { Direct } \\
\text { (embedded) } \\
\text { \& Indirect } \\
\text { (Graduates, } \\
\text { Alumni, } \\
\text { Employers) }\end{array}$ & $\begin{array}{l}\text { Instructor- } \\
\text { developed 4- } \\
\text { tiered rubrics } \\
\text { Course } \\
\text { Materials } \\
\text { Surveys }\end{array}$ & N/A \\
\hline $\begin{array}{l}\text { University } \\
\text { of } \\
\text { Manitoba }\end{array}$ & $\begin{array}{l}\text { Direct \& } \\
\text { Indirect } \\
\text { (Graduate, } \\
\text { Alumni, } \\
\text { Industry, } \\
\text { Students) }\end{array}$ & $\begin{array}{l}\text { Instructor- } \\
\text { developed } \\
\text { rubrics } \\
\text { Surveys }\end{array}$ & N/A \\
\hline $\begin{array}{l}\text { University } \\
\text { of Toronto }\end{array}$ & Direct & $\begin{array}{l}\text { Customizable, } \\
\text { faculty-wide 4- } \\
\text { tiered rubrics }\end{array}$ & N/A \\
\hline
\end{tabular}

Nearly all universities utilize both direct and indirect assessment for graduate attributes as illustrated in Table 4. Indirect assessments typically involved surveying the primary stakeholders of engineering programs to determine their perspective and thoughts on graduate attributes. Nearly all institutions utilize 4-tiered rubrics (Unsatisfactory, Marginal, Meets Expectation, Exceeds Expectations) linked to indicators for assessing graduate attributes. These allow programs to compare students to a minimum threshold and to a target level of performance. Dalhousie and UofT developed faculty-wide rubrics for evaluating indicators and encourage instructors to modify the rubrics to suit their needs. In these cases, the rubrics serve as a starting point and minimal standard for rubrics within the respective institution. The University of Manitoba includes Industry \& Alumni forums, as well as Student-run curriculum forums as a continuous resource for indirect assessment of GA. These forums also allow feedback from industry and alumni regarding their perception of new engineering graduates and increase engagement and awareness of students and educated them about CEAB GA.

Use of learning management systems (LMS) are another common theme with three institutions using a variety of systems to help with assessment, data collection and analysis. These systems allow for ease of data collection and may also serve as a teaching and administrative tool to help with implementing the graduate attribute assessment process. Most notably is Concordia's AAS tool that assists in collecting data, but also collects rubrics allowing for information sharing between instructors evaluating similar attributes. 


\subsection{Curriculum Improvement}

Table 5: Summary of Curriculum Improvement

\begin{tabular}{|c|c|c|c|}
\hline Institution & Plan & $\begin{array}{c}\text { Assessment } \\
\text { Schedule }\end{array}$ & $\begin{array}{r}\text { Current } \\
\text { Status }\end{array}$ \\
\hline $\begin{array}{l}\text { Concordia } \\
\text { University }\end{array}$ & 3 year cycle & $\begin{array}{l}4 \text { GA Directly/yr } \\
12 \text { GA Indirectly/yr } \\
3 \text { staggered groups } \\
\text { resulting in } 2-3 \text { full } \\
\text { assessments per } \\
\text { Accreditation cycle }\end{array}$ & A \\
\hline $\begin{array}{l}\text { Dalhousie } \\
\text { University }\end{array}$ & $\begin{array}{c}\text { Under } \\
\text { Development }\end{array}$ & Under Development & $\mathrm{DC} \& \mathrm{~A}$ \\
\hline $\begin{array}{l}\text { Queen's } \\
\text { University }\end{array}$ & $\begin{array}{c}\text { Annually } \\
\text { (Prof. Spine) }\end{array}$ & $\begin{array}{l}\text { 10-12 GA Directly/yr } \\
12 \text { GA Indirectly/yr }\end{array}$ & $\begin{array}{l}\text { DC, A, } \\
\text { CI }\end{array}$ \\
\hline $\begin{array}{l}\text { University } \\
\text { of British } \\
\text { Columbia }\end{array}$ & $\begin{array}{c}\text { Under } \\
\text { Development }\end{array}$ & Under Development & $\mathrm{DC} \& \mathrm{~A}$ \\
\hline $\begin{array}{l}\text { University } \\
\text { of Calgary }\end{array}$ & $\begin{array}{l}\text { Multi-year } \\
\text { assessment }\end{array}$ & $\begin{array}{l}\text { 4 GA Directly/yr } \\
12 \text { GA Indirectly/yr } \\
\text { 2-3 Data sets per } \\
\text { Accreditation cycle }\end{array}$ & $\mathrm{CI}$ \\
\hline $\begin{array}{l}\text { University } \\
\text { of Manitoba }\end{array}$ & $\begin{array}{l}\text { Continuous } \\
\text { Assessment }\end{array}$ & $\begin{array}{l}4 \text { GA Directly/yr } \\
12 \text { GA Indirectly/yr }\end{array}$ & DC \& A \\
\hline $\begin{array}{l}\text { University } \\
\text { of Toronto }\end{array}$ & $\begin{array}{c}\text { Under } \\
\text { Development }\end{array}$ & Under Development & DC \& A \\
\hline
\end{tabular}

A: Data Analysis, DC: Data Collection, Cl: Curriculum Improvement

Curriculum improvement was another area with differences in approach as seen in Table 5. The multiyear assessment plans or cycles were common with Calgary and Concordia, seeking to lighten the assessment load and allow for focus on a smaller subset of attributes each year. The multi-year plan sets up structured program review, allowing for evaluation of the entire process prior at the middle and end of an accreditation cycle allowing for in-line improvement, should it be required. Queen's University has adopted yearly assessment in its faculty administered "Professional Spine" courses of 10-12 GA, with departmental courses providing additional assessment of yet to be determined attributes. At current, most of these programs are in piloting and testing phases Sections 3.1 and 3.2 and have not reached the full phase of continuous program improvement and 'closed the loop'.

\section{CONCLUSIONS}

Despite some variations, there were many common themes between these institutions in their approach to CEAB accreditation, particularly in curriculum mapping and assessment \& data collection. This summary of approaches will hopefully provide a point of commonality for other institutions and assist in developing their own methods for $\mathrm{CEAB}$ accreditation criteria 3.1 and 3.2. Further information about these approaches, tools and resources along with the EGAD Groups 5-step guide can be found at http://egad.engineering.queensu.ca.

In coming years the institutions described here are targeting development aligned with their institutional priorities. For example the University of Manitoba is redeveloping first year courses to implement discoverybased learning. This effort will ground the learning of electrical circuits, statics, and thermodynamics in laboratory instruction, design exercises, and classroom demonstrations - in this manner the traditional mathematics based curriculum will be augmented with practical engineering applications. Manitoba is also investigating how $C E A B$ attributes manifest in the engineering curriculum, reflect on how they are measured and, explore the extent to which the measurable attributes result in course content proficiency.

Queen's University is continuing to roll out a facultywide four-year sequence of design and professional practice courses, which will serve as the primary experience for developing and assessing attributes including design, professionalism, communications, impact of engineering, ethics, teamwork, and lifelong learning. Queen's is also putting special emphasis into assessing development of problem analysis and critical thinking.

The University of Calgary has been investigating how their Co-curricular Record (CCR) can be incorporated into the Graduate attribute assessment process (https://leadership.ucalgary.ca/about/pageOne.htm). The CCR is the University of Calgary's official document that recognizes a student's out-of-classroom experiences, and is matched to specific learning outcomes that help showcase students' co-curricular skills and capabilities. Students at the University of Calgary have a high level of participation in learning experiences outside the classroom (via support through the Schulich Student Activities Fund), so the CCR appears to be a good fit for the Schulich School of Engineering. They are currently looking at developing an engineering-specific set of CCR learning outcomes that would map directly to the $\mathrm{CEAB}$ graduate attributes. 


\section{Acknowledgements}

The authors would like to acknowledge support from the DuPont Canada Chair in Engineering Education Research and Development. Support for the EGAD initiative, including many of the schools described here, was provided by Engineers Canada and the National Council of Deans of Engineering and Applied Science.

\section{References}

[1] Canadian Engineering Accreditation Board Questionnaire for Evaluation of an Engineering Program 2011, Engineers Canada, available online at http://www.engineerscanada.ca/e/files/Questionnaire 2011_eng_short.doc

[2] Engineering Graduate Attribute Development (EGAD) Project. http://egad.engineering.queensu.ca

[3] P. Wolf, New Directions for Teaching and Learning, Volume 2007, Issue 112 (p 15-20).

[4] ABET, Inc. http://www.abet.org/assessmentplanning/

[5] R. W. Brennan, R. Hugo, and W. D. Rosehart, "CDIO as an Enabler for Graduate Attributes Assessment: A Canadian Case Study," International Journal of Quality Assurance in Engineering and Technology Education (IJQAETE), vol. 2, no. 2, pp. 45-54, 2012.

[6] D. R. Brodeur and E. F. Crawley, "CDIO and quality assurance: Using the standards for continuous program improvement," Engineering Education Quality Assurance, pp. 211-222, 2009.

[7] G. Cloutier and R. Hugo, "Mapping the relationship between the CDIO syllabus and the $2008 \mathrm{CEAB}$ graduate attributes," in Proceedings of the 6th International CDIO Conference. (Montreal, QC; June 15-18) 10 pp., 2010.

[8] B. Kerr, "Using a Web-based assessment tool for accreditation and program improvement," in 4th International Conference on Interactive Collaborative Learning (ICL), (Piestany, Slovakia:Sept 21-23) pp. 534-538, 2011.

[9] B. Frank and D. Strong, "Development of a Design Skill Assessment Tool," in Proceedings of the Canadian Engineering Education Association, (Kingston, ON: June 7-9) 6 pp., 2010.
[10] B. Frank, D. Strong, and R. Sellens, “The Professional Spine: Creation of a Four-year Engineering Design and Practice Sequence," Proceedings of the Canadian Engineering Education Association. (Saint John's, NFLD: June 6-8).11 pp., 2011

[11] B. Frank and S. Fostaty-Young, "What can our students do: Year 2 of graduate attribute assessment at Queen's University," Proceedings of the Canadian Engineering Education Association. (Saint John's, NFLD: June 6-8).6 pp., 2011

[12] G. Cloutier and R. Hugo, "Mapping the Relationship Between the CDIO Syllabus and the CEAB Graduate Attributes: An Update," Proceedings of the 7th International CDIO Conference. (Copenhagen, Denmark: June 20-23). 10 pp., 2011

[13] L. Romkey and S. McCahan, "A Workshop On Learning Objectives For Engineering Faculty Members," Proceedings of the Canadian Engineering Education Association. (Saint John's, NFLD: June 6-8).1 pp., 2011

[14] S. McCahan and L. Romkey, "Beyond Bloom's: Useful Constructs For Developing Graduate Attribute Indicators," Proceedings of the Canadian Engineering Education Association. (Saint John's, NFLD: June 6-8).1 pp., 2011

[15] S. McCahan, G. Allen, and L. Romkey, "Development of the Graduate Attribute Quality Assurance Process at the University of Toronto," Proceedings of the Canadian Engineering Education Association. (Saint John's, NFLD: June 6-8).6 pp., 2011

[16] C. Variawa and S. McCahan, "Investigation Of Language Used In Engineering Assessment," Proceedings of the Canadian Engineering Education Association. (Saint John's, NFLD: June 6-8). 1 pp., 2011 